\title{
The Dynamics of the Library Environment for Professional Staff Growth
}

\begin{abstract}
The career development of librarians requires working conditions to foster this growth. Employee needs for development are summarized and a possible variety of developmental activities are reviewed. Problems in providing or encouraging growth opportunities are discussed. An outline is then provided for desirable general institutional goals and attitudes.
\end{abstract}

A has many problems. Besides financial problems, he must decide how to build collections, what resources in the collections can best serve faculty and students, what kind of bibliographical control must be provided, how to cope with the growth of collections and building problems that ensue, how to make more effective public services, how to provide instruction in library use, and much more. Each of these decisions, furthermore, is dependent on persons for their management: the library staff is ultimately responsible for creating book collections and providing catalogs and services. The people form themselves into an organization having common goals, and it is through people that goals can be achieved.

Despite the great amount of literature on library personnel issues, little attention has been given to the specific topic of how the library personnel environment itself can contribute to the development of professional staff. It is necessary to examine how the organization can

David C. Weber is director of the Stanford University Librories, Stanford, California. motivate staff in their early and midcareer years through the use of participative management, professional advancement, and continuing education so as to satisfy not only the institution's needs for an appropriate and efficiently operated library but also the individual's needs for job satisfaction and career advancement.

This study on the dynamics of library environment and its relationship to professional staff growth examines the problem in four phases: (1) employee needs for professional development-what inhouse encouragement, attention, opportunities are desirable; (2) types of developmental activities that may be used toward meeting these employee needs; (3) problems involved in implementing these various types of activities; and (4) balancing institutional and personal goals where they conflict, weighing costefficiency versus personal benefits, and stimulating development action.

\section{EMPloyee NeEds}

The librarian needs a fertile seedbed for his professional development. An individual usually accepts a position for 
more than salary reasons. For his personal integrity he wishes to feel pride in his work and to identify with an organization and its goals. He expects to work with individuals whom he can respect and from whom he can learn. He wishes to receive encouragement from his supervisor and administrative superiors. To enhance professional prospects, he wants to be part of a group with whom he feels a compatible professional interest, and he wishes to have reasonable opportunity for professional growth. He hopes for individual support in efforts at career advancement, including opportunities to transfer to jobs with more responsibility within the organization and recommendations for such jobs in other libraries. ${ }^{1}$

A summary of these needs is provided in University Library Administration:

The personnel goals of a library are job productivity, the individuals' personal development and satisfaction, and overall library program advancement. These can be promoted through a program of personnel development grounded upon suitable training and supervision. This development is measured by formal performance reviews or achievement ratings. Motivation of staff is not easy of attainment. It is, however, at least as important as salary and fringe benefits in enabling goals to be achieved. ... Good personnel administration will seek ways of satisfying the employee's psychological needs, giving him a feeling of responsibility and accomplishment. $^{2}$

Although these needs of the employee generally do not conflict with those of the organization, there may be some points of difference. To the extent that "job productivity" is emphasized as the organizational goal, most of the activities which might be included in programs for staff development could be precluded. This would, however, be a shortsighted view. Few organizations today have such a narrow conception of efficiency, which is equated to minimum expense for maximum library collections and services. Whenever people are involved, the organization will be only as good as its staff; line employees of today are the managers and administrators of tomorrow.

\section{Types of Developmental Activities}

A comprehensive program to help meet staff development needs might include many types of activities. Ten activities are suggested here; a reasonable program for a university library would encompass most of these.

1. Brief reassignments can be made to other jobs, perhaps across departmental lines, in order to improve orientation to the library program. Such an exchange could be between persons in two departments of the same library or even between two persons in different, perhaps foreign university libraries. This experience can add a great deal beyond knowledge gained in the formal library school training or the introductory orientation program offered all new employees. Such an exchange can provide a substantial learning experience, keeping within the framework of a regular appointment in the library system.

2. Another staff development activity might include planned regular rotation within the library system during the first two or three years of appointment at the beginning level. For example, new librarians might be assigned to work one year in the catalog department before going into any public service position; or new staff might transfer systematically among general reference, government document, and undergraduate library reference departments. Each of these moves would be a true transfer, in contrast to the temporary exchange of assignments in the arrangement above. These transfers probably would be at generally the same level of responsibility and classification.

3. Assignment to library committees 
can play an important role in staff development programs. Committees formed to study proposed policies (for example, confidentiality of certain information), to review a basic management issue (e.g., a complex procedure involving two or more departments), to fill a professional vacancy, to examine graduate programs, to design orientation for incoming students, or to take part in various other library and academic issues enrich the librarian's experience and knowledge, as well as provide contact with faculty, students, and administrators.

4. Another development activity includes membership in professional associations. Within the library there might be a staff association or librarians' association with committees concerned with publications, a staff room, social and cultural programs promoted by the staff, or discussion groups on a wide range of professional matters. Such participation may lead to work with the Special Libraries Association, American Library Association, a regional association, or subject-related professional associations. A book selection specialist or a curator in a particular language field may find work with a committee of the Modern Language Association. Each offers opportunities for library staff to work with colleagues with similar interests in other organizations. The varieties of possibilities here are numerous although the number of opportunities may be very limited for staff in any one library.

5. Another dimension of staff development can derive from visits to university or other academic libraries. These experiences can often be more productive than attendance at professional meetings. Initially, these visits are designed to fulfill a particular need-to develop a building program or to design a new branch library facility; to consult on plans for a book buying trip abroad; or to examine a serial records system. These visits may last for one or two days and commonly result in written internal reports. They also help to serve as an indepth introduction to problems of other organizations.

6. At mid-career levels, there may be occasional consultative opportunities, another development possibility. Whereas most of the previous staff development activities can be initiated by the employee, this one may depend on recommendation from the head librarian. In previous decades there was quite a use of surveys conducted by an expert or a team; nowadays institutions make far more use of individual consultants for building or automation programs without their having to produce a major document. Institutions in the region look to university libraries for providing the experts.

One variation of the consultantship is service as a member of an accreditation team, available sometimes through the initiation of the head librarian and for persons in mid-career. This activity commonly takes the form of joining a committee composed of various specialists. The committee spends two or three days in a consultative role with the academic institution wishing to be reaccredited and submits its evaluation and suggestions in a report to the accrediting association. These experiences not only help the institution visited but also materially contribute to the continuing education and professional stimulus of the participating staff member.

7. Another development activity, which may be initiated either by the employee or by the library administration, is writing and publishing. These opportunities are available more often than assumed to be the case by the employee. Local library bulletins, campus newspapers, and state library journals are but a few of the dozens of outlets. Every university library has problems which, if properly analyzed and described, may make suitable professional contributions in the 
published literature. This includes the preparation of literature bibliographies, which may serve a public service function of the local library and in turn may become official library publications. The experience of organizing one's thoughts and submitting them to public scrutiny, no matter how small the audience, is a significant dimension of staff development opportunities. Both criticism of and support for published material further the individual's analytical powers and reasoning.

8. A somewhat more ambitious development opportunity includes research or sabbatical leave. Although less frequent than the previous opportunities, sabbaticals are designed to give time for a major study, which may include travel, research effort, and writing. The purpose is serious and scholarly, justifying the three to twelve months with salary support. In few institutions are they available for librarians who have passed the probationary period but have not yet been promoted to the senior grades of librarian. There should be many more institutions offering sabbaticals for librarians submitting substantial research proposals. The opportunity for sabbaticals merely reflects the rapidly changing nature of librarianship and the consequent need for university librarians to keep up with advances in their field as does the faculty of a university.

9. Workshops, seminars, institutes, and non-credit courses provide another development activity. A considerable range of library institutes and mini-courses now exists: ALA conference programs start with several institutes; the Office of Education has funded institutes offered by a great many library schools around the country; and many universities provide brief courses ranging from two days to a week, sometimes as part of extension programs and often as part of a deliberate university policy to utilize the physical plant during the summer and bring in income at times when students are not filling facilities. In a local context, courses can be part of a university-wide staff development program, which may include, for example, a series of sessions on supervisory training-one of the major needs in universities and in their libraries. Other mini-courses can be specially developed within the library to serve particular needs, such as a program to explore staff implications of library automation, or the integration of micro-formats into the several departmental programs of the library, or a brief course on utilization of social science data tapes.

10. Finally, formal support could be given for librarians wishing to audit a course on instruction or to pursue a degree program. This would require a policy of permissible time-off and reimbursement for partial or complete expense entailed in the program. This is the most ambitious of library arrangements to promote the development of professional staff.

These ten activities can contribute significantly to the job-related development of professional personnel. Although additional activities or variations in these programs can be pursued, these ten are intended to show the very wide range of alternatives available to enhance development through broader educational experience. They constitute a continuum, starting from simple, informal, and brief efforts and extending to far more ambitious, time consuming, and formal programs. $^{3}$

\section{Problems of IMPLEMENTATION}

The actual problems resulting from these staff development activities deserve practical consideration. In contrast to the theory of development opportunities, ten types of practical problems are examined in weighing consequent advantages and disadvantages of implementing staff development programs. 
1. The quality of supervision is critical in putting development activities into practice.

The good supervisor will convey a sense of the 'mission' of the library, will explain how each task is important to the overall effectiveness, will show interest in the individual's job problems, and will encourage suggestions for improving the organization. Participative-management theory states that employees are motivated by drawing them into the decision-making process so they can relate their personal goals and achievements to those of the organization. This philosophy is increasingly important in libraries as they become highly organized with hundreds on their staff. 4

Where libraries have a professional staff of 50 to 150 persons situated in from ten to thirty different buildings, each supervisor becomes a critical person in the organization.

The supervisor receives information and various signals from the immediate superior and passes them on to subordinate staff. The information will be so conveyed as to reflect the supervisor's values and attitudes, which in some cases may be discouraging of staff development, for whatever personal reason. The supervisor may subconsciously be less than enthusiastic about staff development, perhaps because he or she did not have ample opportunity in the early career years, or does not now feel there is a chance for further development; because of a feeling of pressure from above for quantitative achievement; or a host of other reasons. As library organizations grow, attitudes, techniques, and leadership qualities used by the supervisor become more important. University libraries should pay more attention to the development of these individuals because of the effect they have on the entire organization. Knowledge of the library organization, its policies and goals, a good working relationship with de- partment heads, the director, and associate directors of the library, and a sensitive, responsive, judicious warmth toward the individual employee are essential qualities for this staff officer. Not merely an advocate of the administration nor only a spokesman for the employee, the supervisor works in that difficult realm between both parties. Several options under a staff development program, such as brief reassignments or even transfers, depend entirely on this officer for effectiveness. The supervisor will not always be effective in this development role.

2. The nature of a temporary transfer constitutes a second problem. The caliber of exchanged employees is never equal. Thus, one department will feel it is giving up much more than it gains; indeed the other department may also hold that view. Even though the director of libraries believes transfers are desirable for the general good of the organization or for public relations, this may not be the case at the working department level. A reassigned employee requires almost as much training as does a regular new employee, prompting the supervisor or department head to have less enthusiasm for transfers unless he is confident that the person out on loan from his department will return with a great deal more effectiveness in the organization.

The library school programs at the University of Texas and the University of Washington build in such field experience prior to employment and require a range of assignments during the month or two of internship. Because the program is limited to interns, however, the assignments obviously cannot provide the same level of responsibility as for a permanent employee. The library trying to offer temporary transfers early after employment must find ways of minimizing the practical difficulties in their execution. 
3. Timing often constitutes a real inhibition to many administrative actions, not least of which is staff development. An academic year has its rhythm with an established timing for committee appointments, leaves, and budgetary planning, as well as personnel decisions, which in turn affect reassignments or transfers. Work must be reassigned or substitutes hired if a librarian is going to leave. Leave for six months with full pay requires funds to cover temporary help, if indeed a suitable temporary replacement can be found. The individual's requirements may also be affected by a spouse's ability to get away from the job, or when children will be out of school. If the individual is operating a one-librarian branch library, for example, the library administration's support for that individual's sabbatical will understandably be less than enthusiastic. Secondary issues may demand considerable advance thought: deadlines that may be required for certain applications; advance coordination if jobs are to be exchanged; support requirements for clerical assistants if there is heavy committee work. Timing, as well as the time required, are occasionally significant elements limiting the effective pursuit of staff development programs.

4. Another limiting factor derives from the fact that a library is part of the university. The library therefore cannot unilaterally adopt a staff benefit program which will place it ahead of other departments or set a precedent that will cause unwanted repercussions elsewhere. An example may be a request for sabbaticals for junior professional staff when research associates whom the academic vice-president considers a comparable group have asked and been refused. Or tuition reimbursement for part-time graduate study of full-time library employees may be vetoed if a similar benefit could not be funded on a universitywide basis.
5. Another point is the direct costs entailed. These costs include the time of the employee as well as other, less direct, participants. It would be possible to put a dollar figure on each kind of staff development effort and each action under such a program, including not only the individual but his supervisor, department chief, the head librarian, personnel officer, and perhaps one or several university offices outside the library. Therefore, far more expense is incurred than merely the time of one employee. When budgets are tight, this expense can exercise a considerable braking effect on staff development programs and their individual components. In terms of library budget priority, there may be pressure for items among which the adoption of some one staff development program may have to take a lower budgetary priority when the consequences of not funding each are evaluated and compared.

6. Time is money and it is therefore least expensive if one department head or the head librarian makes a rapid decision. But this is not the way to develop staff and increase the responsibility of young librarians. This problem derives from the delay in making a decision and implementing the action, rather than the actual dollar cost. A search committee is a good example. Although the quality of the final decision may be improved by a search committee, and it helps participants better understand management problems and decisionmaking processes, it might take extra time to decide on a professional appointment-or to plan a branch library building, or revise its borrowing privileges policy statement. Some issues certainly can be given that extra time; as the retirement date of a staff member is known well in advance, a search committee can be started in good season. On other issues with close deadlines, however, the extra time required presents such time 
difficulties that some types of staff involvement that can contribute to staff development may not work smoothly and are thus seldom pursued.

7. Inflexibility may present a problem in a very small staff. In an office run by one person or in a branch library with one librarian or with an individual who is the sole subject expert, the priority requirement is to keep these operations going. An individual in such an organization thus would have more difficulty finding certain opportunities for staff advancement than one who is on a team of several in a general reference department. These are practical inhibitions on staff development; and the great majority of librarians, even in a university with a staff as large as Stanford's 140 professionals, will find that only a small number are team members and thus can be more easily spared and their responsibilities reassigned. Even in a reference department, each librarian may have a different set of special responsibilities so that arrangements to transfer such a person even in a large unit are by no means simple.

8. A library administration must consider that after investing in the development of a staff member, the individual may soon resign to accept a more attractive position elsewhere. The librarian who has attended an institute, visited other institutions, given a paper at a professional meeting, or had a research leave has a wider geographic visibility. The individual who seeks self-aggrandizement may use such activities to find better jobs elsewhere. Only if the employee gives evidence of unconscionable self-interest, if he fails to recognize that he is an employee with obligations to the institution, would the wise library administrator oppose a development activity because of possible loss of the employee.

Library administrators recognize the need for a reasonably stable operation.
This does not mean, however, that personnel is stable. It is in fact volatile-5 to 10 percent sometimes turning over in any one year. It is almost unheard of for any librarian today to come out of a graduate library school and stay in one institution until retirement. It is normal, because of the pyramidal shape of a library staff, for most to move a few times within one institution and/or move on to more responsible jobs elsewhere. Indeed, it is for the good of the organization, the individual, and the profession for this mobility to occur. In addition, a certain proportion of the senior jobs in any university library will be filled by persons who have been brought in from outside, employees who have found ways of staff development and gained recognition at another institution. Yet volatility might still be considered a problem in some aspects of staff development.

9. Another concern is the general administrative burden on the library directors, department heads, and personnel office. It often takes an extra effort on their part to see how advancement can be facilitated, to review staff members for promotion to an upcoming vacancy, to suggest attendance at an institute, and so forth. Although some opportunities can be initiated by the employee, in practice a majority are initiated by the administrative group. Therefore, the caliber and concern of the personnel officer and others in the top administrative group are critical. For these individuals this is but one more administrative responsibility, and quite often it must be with substantial extra effort.

10. Another problem has been pointed out by Guy R. Lyle, who speaks of low salaries, relatively long hours, and frequent understaffing as three obstacles to the continuing education of the library staff. He goes on to add a fourth, saying:

Even under the best of conditions, librarianship has a tendency to become 
routine and largely automatic. There is routine work even in duties which are predominantly professional, and a great deal more of that in work that goes on behind the scenes. There is the ever present danger that such routines will induce a sense of complacency and an acceptance of things as they are. ${ }^{5}$

This preoccupation with daily routines, the problems of catalog records and book collections, the problems of a seemingly petty nature on top of these that seem insurmountable result in a centrifugal force which propels the librarian to the myriad mundane but practical matters rather than coming into the heart of librarianship: its philosophy of collection development, service, and the best utilization of staff and other resources. It takes a strong counterforce to overcome this sense of tradition, this condition of complacency, the need for stability in a major and expensive and often understaffed service organization.

\section{BALANCING INSTITUTIONAL AND Personal Goals}

The dynamics of this environment are complex. The interaction of development opportunities and related problems needs to be adjusted so as to create an effective personnel environment, especially for the early and mid-career advancement of professional staff. The administrator must find a reasonable balance in priorities between the institution's immediate needs for service and efficiency and the employees' personal goals of satisfaction, recognition, development, and advancement possibilities. Costs and benefits or time required and value derived must be weighed.

There is no one answer to the set of problems, but a general position may be stated. Although during the most austere financial periods the opportunities for staff development may be curtailed, in more normal times an institution and its library should offer a great many of the suggested developmental opportunities. Not necessarily all types of staff development can be supported in every institution or at the same time, but certainly a fair range should be offered.

Libraries have grown rapidly in the past twenty-five years, and changing service requirements and economic, machine, and systems factors require that librarians continue to develop their professional knowledge of theory and techniques in order to serve their institutions effectively. Furthermore, the director or manager is but one person expending effort. The line staff are those many whose combined efforts provide the front-line service. The lower the level at which work is achieved, the more powerful the total accomplishments of the organization. To this end, when a manager can shift attention from the pressure of immediate tasks, he is interested in (1) raising the level of employee motivation, (2) increasing the readiness of subordinates to accept change, (3) improving the quality of all managerial decisions, (4) promoting teamwork and morale, and (5) furthering the individual development of the staff. As analyzed by Tannenbaum and Schmidt, most research and much of recent experience "give a strong factual basis to the theory that a fairly high degree of subordinate-centered behavior [as the style of management's leadership] is associated with the accomplishment of the five purposes mentioned." They add that "to provide the individual ... with greater freedom than they are ready for ... may very well tend to generate anxieties and therefore inhibit rather than facilitate the attainment of desired objectives. But this should not keep the manager from making a continuing effort to confront his subordinates with the challenge of freedom." 6 The successful organization, then, is one which stim- 
ulates the growth of junior staff and provides them considerable participative freedom.

An administrator realizes that if too much upward mobility were generated he would find that the institution is really running a postgraduate course in library administration. Individual circumstances, however, resolve this problem. Not every librarian can be or wishes to be part of the administrative structure of the library. For many librarians development occurs in a nonadministrative path. Those staff who have ability and motivation and show initiative should be encouraged by all means, including the staff development programs here cited.

The most effective way to increase the viability of a professional development program, given the problems inherent in its application, depends on the vigor with which this is personally pursued among the highest levels of the library's administration. Those officers will need to keep this in mind, to find ways of stimulating the department heads, to raise the issue whenever development opportunity presents itself, to understand the individual interests of professional staff, and to know what action is or is not possible in administrative terms when a propitious moment arrives. It requires a basic desire to make this work. Whether a staff development program is called "continuing education," whether parts of it are referred to as "participative management" or "good sense," the key library officers need to promote this as a centrally important part of their program, not as an afterthought and not as an area to be given token effort.

In these times, staff development is the single most significant aspect of a satisfactory long-term personnel program. The dynamic nature of staff relationships, the host of shifting sets of problems, and the uncertain priority in budget programs make its implementation extraordinarily difficult. It is, despite this, a major factor in fashioning a quality university library.

\section{REFERENCES}

1. Note that relations with professional colleagues and "further developing professional experience" were the most important job satisfaction factors in both first and second posts of 1965-71 graduates in librarianship from Sheffield University. Norman Roberts, "Graduates in Academic Libraries: A Survey of Past Students of the Post-Graduate School of Librarianship and Information Studies, Sheffield University, 1964/65-1970/ 71," Journal of Librarianship 5:106-11 (April 1973).

2. Rutherford D. Rogers and David C. Weber, University Library Administration (N.Y.: H. W. Wilson Co., 1971), p.45-46.
3. A useful group of articles on "Personnel Development and Continuing Education in Libraries" comprises the July 1971 issue of Library Trends, edited by Elizabeth W. Stone.

4. Rogers and Weber, University Library Administration, p.46.

5. Guy R. Lyle et al., The Administration of the College Library (3d ed.; N.Y.: H. W. Wilson Co., 1961), p.206.

6. Robert Tannenbaum and Warren H. Schmidt, "How to Choose a Leadership Pattern," Harvard Business Review 36:101 (March/April 1958). 